\title{
Effect of Cherry Extract and Almond Oil on Oxonic cid-Induced Hyperuricemia in Male Albino Rats
}

\author{
ChrakhanJ. Khdhir ${ }^{1}$, Ridha H. Hussein ${ }^{1}$ and Hoshyar A. Azeez ${ }^{2 *}$ \\ ${ }^{1}$ Biology Department, College of Science, Sulaimani University. \\ ${ }^{2}$ Pharmacognocyand pharmaceutical Department, College of Pharmacy, Sulaimani University, Iraq. \\ *Corresponding author: hoshyar.azeez@univsul.edu.iq
}

\begin{abstract}
This study designed to investigate the effects of cherry extraction, almond oil, and their combination on physiological and some biochemical parameters in oxonic acid-induced hyperuricemic rats. Hyperuricemia was induced experimentally by intraperitoneal injection of rats with oxonic acid (OA) $(250 \mathrm{mg} / \mathrm{kg} / \mathrm{bw})$ daily for two weeks. The animals were randomly divided into six groups each included six rats: normalcontrol, Hyperuricemic (HU), HU+ Allopurinolas a positive control (AP) $(5 \mathrm{mg} / \mathrm{kg} / \mathrm{bw})$, HU+ Cherry extract $(500 \mathrm{mg} / \mathrm{kg} / \mathrm{bw})$, HU+ Almond oil $(3 \mathrm{ml} / \mathrm{kg} / \mathrm{bw})$, and $\mathrm{HU}+$ co-treatment of (Cherry extract+ Almond oil). The treatments were administrated orally by intragastric tube (gavage) $1 \mathrm{~h}$ after OA injection daily throughout the study.At the end of the experiment, the rats were fasted overnight, anesthetized then blood samples were collected for biochemical analysis and detection of oxidative stress.Results indicated that injection with OA induced hyperuricemia after two weeks in rats by increasing the level of serum uric acid significantly $(\mathrm{P} \leq 0.0001)$, and a significantelevation in the levels of $\mathrm{BUN}, \mathrm{SCr}, \mathrm{XO}$, and LPO were observed, whereas the level of serum SOD decreased.Moreover, treatment with HU rats with AP, cherry extract and almond oil alone and in their combination group, all significantly decreased SUA, SCr, BUN (except for the almond oil group in which Scr and BUN decreased nonsignificantly)and reversing the results of oxidative stress. Finally, the results showed that the effects of combined treatment (cherry extract + almond oil) was near the actionsof allopurinol.
\end{abstract}

[DOI: $\underline{10.22401 / A N J S .22 .4 .08]}$

Keywords: oxonic acid, hyperuricemia, oxidative stress, cherry extract, almond oil.

\section{Introduction}

Gout is a rheumatic condition characterized by deposition and accumulation of monosodium urate crystal around joints. People with gout often experience acute and recurrent arthritis attacks that can affect multiple joints [1]. Hyperuricemia or excessive circulating urate concentrations, which is the final product of purine metabolism, is an important risk factor for gout and plays a significant role in the pathogenesis of this condition [2]. A cardinal precursor of gout arthritis and renal disease is hyperuricemia. It contributes significantly to the elevating incidence of chronic, degenerative and preventable diseases in the lifestyle [3].

The main approach to hyperuricemia treatment is the development of xanthine oxidase inhibitors that are more effective in reducing the level of uric acid in the plasma and urine and reverse the development of tophaceous deposition [4]. In spite of advances in the use of anti-hyperuricemic agents for the treatment of hyperuricemia and gout, allopurinol as a xanthine oxidase inhibitor could induce severe hypersensitivity and agranulocytosis, exacerbating renal toxicity by damaging the metabolism of pyrimidine [5]. Therefore, the available anti-hyperuricemic agents, particularly extracts of some plant medicines, need to be studied.

For thousands of years, natural products, mainly plants, were been used to cure various diseases. There are several species of plant medicines commonly used in the treatment, Prunus spp. belongs to the family Rosacea, and it is a medicinal plant popularly used for the treatment of many diseases [6].

Cherries have attracted considerable public attention and interest in gout prevention and management from both patients and researchers as a potentially effective option. Small experimental studies in healthy humans and animals have shown that cherry reduces 
uric acid levels in the serum [7]. Others have shown high levels of phenolic compounds (among them anthocyanins) in cherries products which have antioxidant and antiinflammatory properties [8].

Almond (Prunus amygdalus) oil as the most popular vegetable oilsis rich in mono and polyunsaturated fatty acids, with the main constituents being oleic and linoleic acids and several minor components such as tocopherols and phenolic compounds [9],diets that are rich in these compounds can prevent oxidative stress [10]. Some studies have demonstrated the antioxidant activity and free radical scavenging capacity of almond oil.In view of that, this study was aimed to investigate the role of cherry extract, almond oil and the combination of them in improving oxidative stress and physiological changes in oxonic acid-induced hyperuricemicrat model by evaluating certain biochemical parameters.

\section{Materials and Methods Experimental animals}

Thirty six adult male albino rats (Rattus norvegicus) of about 180-200 g body weight and 8 to 12 weeks old were used; animals were kept in the animal house.Six animals were kept in each cage in a controlled environment that was maintained under a 12 hour light/dark cycle, a temperature of $22 \pm 4^{\circ} \mathrm{C}$, and the rats were supplied with a standard pellet diet and tap water ad-libitum.

\section{Plant collection and preparation of extract}

Fresh cherry Prunus spp. fruits were collected from Sitek-Sulaimani region, in June, and identified by the Taxonomist Shewa F. Mahmood, College of Science Biology Dept. Fruits were taken and dried under shade, then powdered by a mechanical grinder and stored in airtight containers. Cherry extracts were made by soaking $1 \mathrm{~g}$ of powder to50 ml of $70 \%$ ethanol for $48-72 \mathrm{~h}$. The solution was filtered and concentrated in a rotatory evaporator. Finally, the sample was lyophilized by freeze drying to powder and kept in a dark container at $4^{\circ} \mathrm{C}$ until use [11].

Almond Prunus amygdalus seeds were bought from a local market in Sitak-Sulaimani region. The seeds were dried in anoven at $50^{\circ} \mathrm{C}$ for $1 \mathrm{~h}$ and powdered. The oil was extracted using soxhlet apparatus by placing $50 \mathrm{~g}$ of the powder into a thimble with $\mathrm{n}$ hexane for $6 \mathrm{~h} \mathrm{[12].}$

\section{Solution preparation}

Oxonic acid (OA) was purchased from Angene, China then $250 \mathrm{mg} / \mathrm{kg} / \mathrm{bw}$ was dissolved in $0.9 \%$ saline solution [13]. Allopurinol (AP) (gsk-India) $(5 \mathrm{mg} / \mathrm{kg} / \mathrm{bw})$ and cherry extract $(500 \mathrm{mg} / \mathrm{kg} / \mathrm{bw})$ were dispersed in distilled water [14].

\section{Induction of hyperuricemia}

Experimentally, hyperuricemia was induced by the administration of oxonic acid (250 $\mathrm{mg} / \mathrm{kg} / \mathrm{bw}) \quad$ intraperitoneally(IP) [13],once a day to each animal for two weeks.

\section{Experimental design}

The experimental rats were divided into 6 groups, with 6 rats in each group:

G1:normal rats which received intraperitoneal injectionof $0.9 \%$ saline solution (Control).

G2:Hyperuricemicrats (HU)which received Oxonic acid $(250 \mathrm{mg} / \mathrm{kg} / \mathrm{bw})$ (Model).

G3: $\mathrm{HU}+$ Allopurinol (AP) $(5 \mathrm{mg} / \mathrm{kg} / \mathrm{bw})$. (Positive control).

G4: HU+ Cherry extract $(500 \mathrm{mg} / \mathrm{kg} / \mathrm{bw})$.

G5: $\mathrm{HU}+$ Almond oil $(3 \mathrm{ml} / \mathrm{kg} / \mathrm{bw})$.

G6:HU+ Co-treatment (Cherry extract + Almond oil).

The treatments were administered to rats orally by intragastric tube (gavage) daily $1 \mathrm{~h}$ after OA injection throughout the study period (two weeks).

\section{Collection of blood samples}

At the end of the study, the rats were fasted overnight and then anesthetized with an intraperitoneal injection of a combination of ketamine hydrochloride $(50 \mathrm{mg} / \mathrm{kg} / \mathrm{bw})$ and xylazine $(5 \mathrm{mg} / \mathrm{kg} / \mathrm{bw})$ [15].Through cardiac puncture,blood samples were collected into thegel tubes and centrifuged at $3000 \mathrm{rpm}$ for 15 min. Finally, the serum obtained was analyzed for biochemical parameters.

\section{Estimation of serum biochemical parameters and oxidative stress}

Serum uric acid (SUA), serum creatinine (SCr) and blood urea nitrogen (BUN) were determined in the serum by using automatic 
biochemistry analyzer (Cobas C311, RocheGermany).Serum levels of xanthine oxidase (XO), lipid peroxidation (LPO) and superoxide dismutase 1 (SOD1) were measured by enzyme-linked immunosorbent assay (ELISA) kits purchased from Fine test, China).

\section{Statistical analysis}

Data were analyzed using the software version 8.1 of the statistical program GraphPad (Prism 2019) using one way and multiple comparisons of ANOVA and Tukey Technique for descriptive analysis.

\section{Results and discussion}

Oxonic acid-induced hyperuricemic rats showed significant $(\mathrm{P} \leq 0.0001)$ elevation in the level of SUA $(4.250 \mathrm{mg} / \mathrm{dL})$, highly significant in the SCr level $(\mathrm{P} \leq 0.01)(0.3825 \mathrm{mg} / \mathrm{dL})$ and significantly in the BUN level $(29.58 \mathrm{mg} / \mathrm{dL})$ when compared to control rat group Table (1). Similar results were obtained by previous experimental hyperuricemic study [14], who revealed that oral administration of OA (250 $\mathrm{mg} / \mathrm{kg} / \mathrm{bw}$ ) once daily for 7 days induced hyperuricemia in model rats, in which SUA, $\mathrm{SCr}$, and BUN levels increased significantly, when compared to the normal control group.

Oxonic acid caused hyperuricemia in rats for the reason that injectingOA in rats stimulates xanthine oxidase to produce excess uric acid, also OA blocks the effect of hepatic uricase which leads to an increase in the level of uric acid and produces hyperuricemia in animals $[16,17]$.

Blood urea nitrogen and creatininelevels are useful indicators of renal function. Renal damage is accompanied by an increase in BUN and $\mathrm{SCr}$ indicating reduced urea and creatinine clearance [18]. Clinical reports have shown that hyperuricemia is associated with not only gout but also chronic nephritis and renal dysfunction [19].Previous study[20] indicated that hyperuricemia can accelerate the progression of renal damage, and uric acid is the causative agent in the nephropathy.

Treatment of hyperuricemic rats with AP significantly lowered SUA level (1.200 $\mathrm{mg} / \mathrm{dL}$ ), high significantly reduced the level of $\mathrm{SCr}(0.2725 \mathrm{mg} / \mathrm{dL})$, and significantly lowered BUN level (20.90 mg/dL) as compared to their respective model rats.Similar results were documented by [21], in which oral administration of $5 \mathrm{mg} / \mathrm{kg} / \mathrm{bw}$ of allopurinol to hyperuricemic rats reduced SUA, $\mathrm{SCr}$ and BUN significantly. Allopurinol significantly reduced uric acid levels and blocked the renal functional and histologic changes that decrease SUA level by inhibiting the enzyme xanthine oxidase and slowing the progression of renal disease [20, 22]. Moreover, the study of [23] demonstrated that allopurinol treatment prevented thickening of afferent arterioles and glomerular hypertension and partially prevented the cortical ischemia. Moreover, Allopurinol treatment restored the functional changes and it fully prevented arteriolopathy.

In the present study, treatment of hyperuricemic rats with cherry extract and cotreatment (cherry extract + almond oil) decreased SUA level extreme significantly $(2.550 \mathrm{mg} / \mathrm{dL}$ and $2.525 \mathrm{mg} / \mathrm{dL})$ respectively, also $\mathrm{SCr}(0.2925 \mathrm{mg} / \mathrm{dL}$ and $0.2900 \mathrm{mg} / \mathrm{dL})$ and BUN (22.0 0mg/dL and $21.98 \mathrm{mg} / \mathrm{dL})$ levels were reduced significantly when compared to their model rats. This result is in agreement with previous study [7], in which evaluated the hypouricemic effects of cherry juice in hyperuricemic rats, and oral administration of cherry juice $(5 \mathrm{ml} / \mathrm{kg} / \mathrm{bw})$ reduced SUA significantly within two weeks. Also, [24] exhibited that treatment of hyperuricemic mice with phytochemicals of Rhododendron oldhamii Maxim. Leaf extracts significantly reduced kidney injury, and the SUA level was significantly suppressed. The hypouricemic property of cherry can be explained by its inhibitory effect on xanthine oxidase (XO) and xanthine dehydrogenase (XDH) activity [7], and numerous studies have shown that phenolic compounds were found in plants, such as anthocyanins and quercetin, inhibit XO and XDH activity, thus reducing hyperuricemia. In addition, [25] reported that the predominant mechanism of biological actions of the cherry has resulted from antioxidant activity, enzyme inhibition, and the capacity to scavenge free radicals.

However, treatment of hyperuricemic rat with almond oil alone significantly reduced SUA level $(3.200 \mathrm{mg} / \mathrm{dL})$, this result agrees with [26], in which oral administration of cassia oil significantly reduced serum urate levels in hyperuricemic mice in a time and 
dose-dependent manner. But oral administration of hyperuricemic rats with almond oil not significantly decreased $\mathrm{SCr}$ $(0.3350 \mathrm{mg} / \mathrm{dL})$ and $\mathrm{BUN}(29.10 \mathrm{mg} / \mathrm{dL})$. This result disagrees with [6], who reported that administration of almond extract orally atdifferent doses for 21 days significantly reduced blood creatinine and urea levels after treatment. The almond seed oil has antioxidant effects since it is arich source of vitamin- E, monounsaturated fats and phytosterols [9]. Due to these properties, almond oil hashypouricemic action which decreased SUA. But maybe time and the dose required for improvement of $\mathrm{SCr}$ and $\mathrm{BUN}$. Figures (1, 2 and 3) showed the effect of treatments on SUA, SCr and BUN levels.

Table (1)

Effect of cherry extract, almond oil and their combination on SUA, SCr, and BUN in hyperuricemic rats

\begin{tabular}{|c|c|c|c|}
\hline Groups parameters & $\begin{array}{l}\text { Uric acid } \\
\text { mg/Dl }\end{array}$ & $\begin{array}{c}\text { Creatinine } \\
\text { mg/dL }\end{array}$ & $\begin{array}{c}\text { Blood Urea } \\
\text { nitrogen } \\
\text { mg/dL }\end{array}$ \\
\hline $\begin{array}{l}\text { Normal } \\
\text { (control) rats }\end{array}$ & $1.150 \pm 0.1190^{\mathrm{a}}$ & $0.2700 \pm 0.01080^{\mathrm{a}}$ & $21.35 \pm 1.398^{\mathrm{a}}$ \\
\hline $\begin{array}{l}\text { Hyperuricemic } \\
\text { (HU) rats }\end{array}$ & $4.250 \pm 0.4031^{\mathrm{c}}$ & $0.3825 \pm 0.01887^{\mathrm{b}}$ & $29.58 \pm 0.5452^{\mathrm{c}}$ \\
\hline $\begin{array}{l}\text { HUt } \\
\text { Allopurinol (AP) }\end{array}$ & $1.200 \pm 0.1080^{\mathrm{a}}$ & $0.2725 \pm 0.01652^{\mathrm{a}}$ & $20.90 \pm 3.165^{\mathrm{a}}$ \\
\hline $\begin{array}{l}\text { HU+ } \\
\text { Cherry extract }\end{array}$ & $2.550 \pm 0.2327^{b}$ & $0.2925 \pm 0.01702^{\mathrm{a}}$ & $22.00 \pm 1.116^{\mathrm{ab}}$ \\
\hline $\begin{array}{l}\text { HUt } \\
\text { Almond oil }\end{array}$ & $3.200 \pm 0.2345^{b}$ & $0.3350 \pm 0.01708^{a b}$ & $29.10 \pm 1.540^{\mathrm{bc}}$ \\
\hline $\begin{array}{l}\text { HUt } \\
\text { (Cherry +Almond oil) }\end{array}$ & $2.525 \pm 0.1887^{b}$ & $0.2900 \pm 0.01581^{\mathrm{a}}$ & $21.98 \pm 0.4171^{\mathrm{ab}}$ \\
\hline
\end{tabular}

Value are expressed as mean \pm S.E. Different letters indicate significant differences between means $*=\mathrm{p}<0.05, * *=\mathrm{p}<0.01, * * *=\mathrm{p}<0.001$

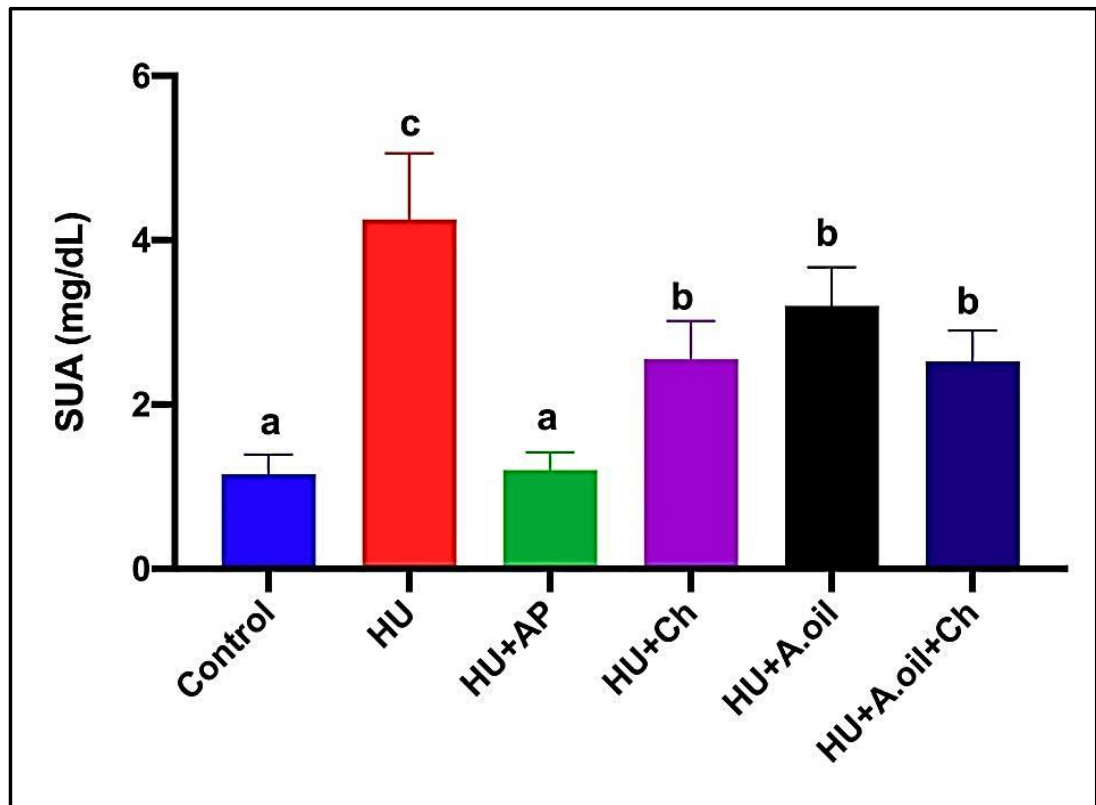

Fig.(1): Effect of cherry extracts, almond oil, and their combination on Serum uric acid in hyperuricemic male rats. 


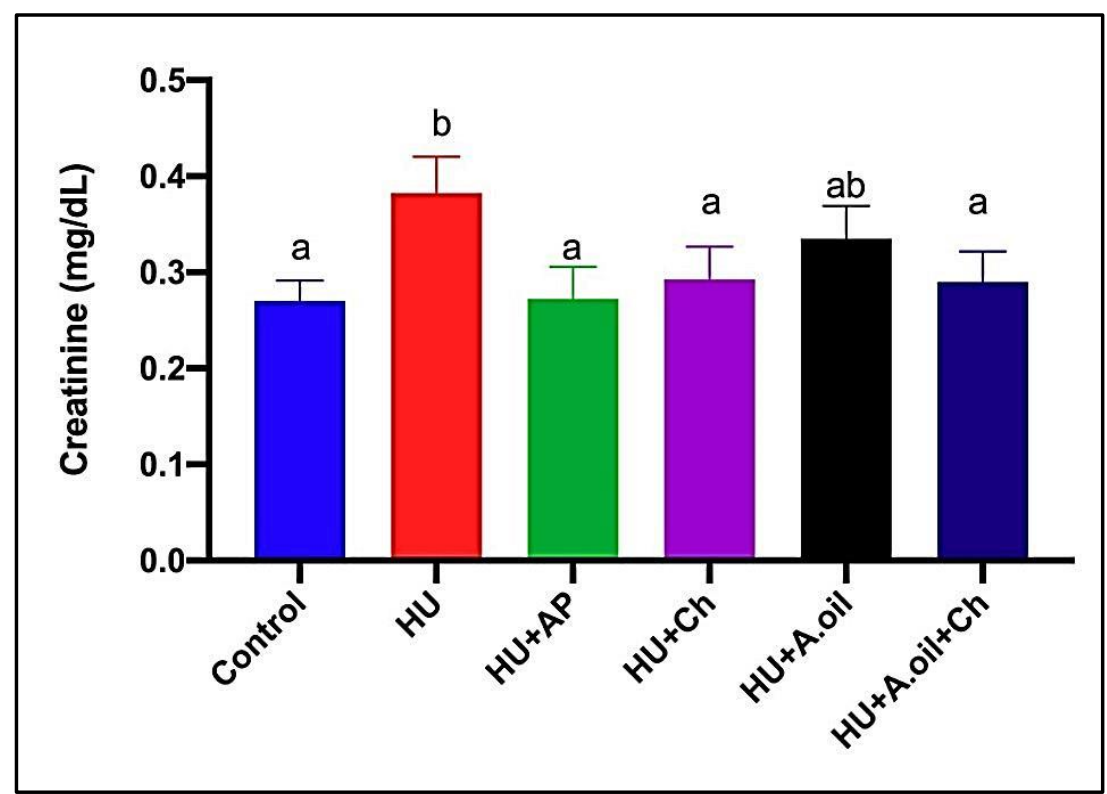

Fig.(2): Effect of cherry extract, almond oil, and their combinationon Serumcreatinine in hyperuricemic male rats.

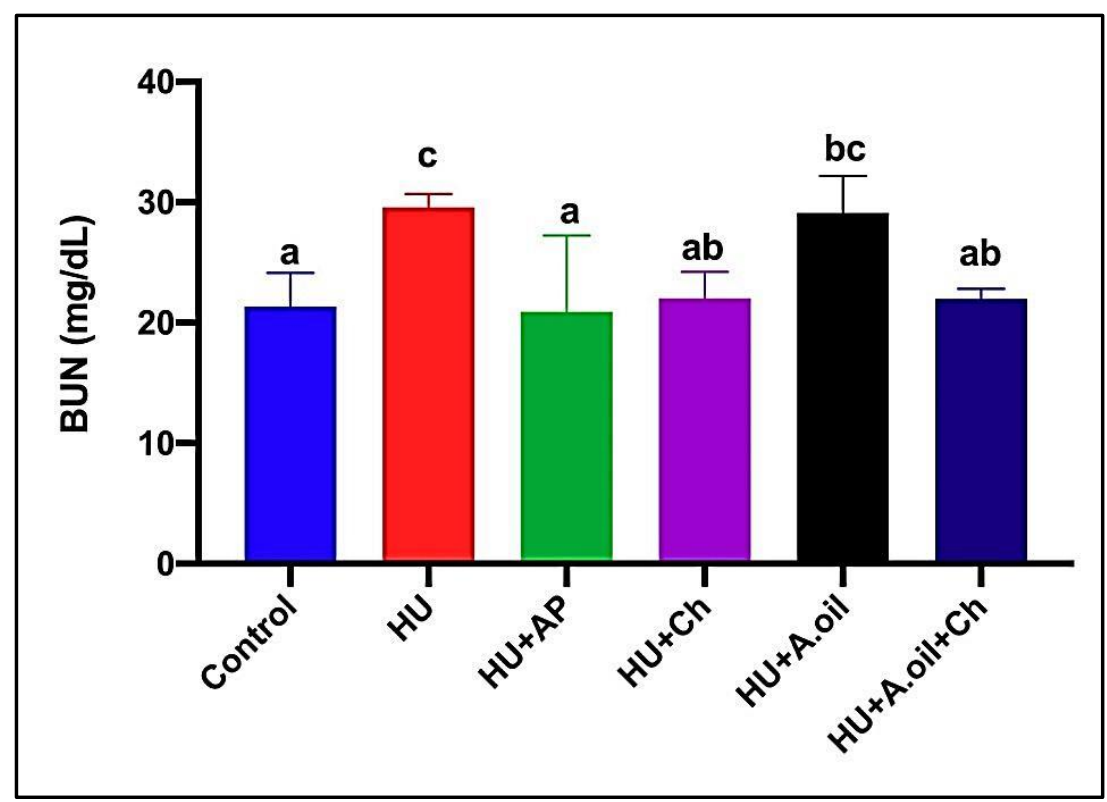

Fig.(3): Effect of cherry extract, almond oil, and their combinationon Bloodurea nitrogen in hyperuricemic male rats.

Hyperuricemic rats showed a significant elevation in the levels of serum (XO) $(3.151 \mathrm{ng} / \mathrm{ml})$ and significant increase in the level of serum lipid peroxide (LPO)(44.88ng/ml), and a highlysignificant reduction in serum superoxide dismutase (SOD 1)level $(1.025 \mathrm{ng} / \mathrm{ml})$ indicating the oxidative stress in hyperuricemic rats, as shown in Table (2). Similar results were approved by previous hyperuricemic study, in which after 3 and $6 \mathrm{~h}$ from $\mathrm{OA}$ injection $(250 \mathrm{mg} / \mathrm{kg} / \mathrm{bw})$, hyperuricemic rats showed a significant increase in erythrocyte sedimentation rate (ESR), nitric oxide and malondialdehyde (MDA) levels compared with normal rats. This represented the inflammatory condition and elevated oxidative stress [13].Also, the level of XO significantly increased in hyperuricemic rats after $\mathrm{OA}$ injection [21].

Hyperuricemia increases oxygen free radical production and resultant oxidative stress. It causes oxidative stress and an interrelatedto vascular inflammation, and endothelial dysfunction, which leads to oxidative damage of lipids and proteins [27]. 
Urate has dual nature ofoxidative stress, which can act both as an antioxidant and a prooxidant [28]. Under normal physiological conditions, uric acid acts as an antioxidant in plasma, and uric acid acts as prooxidant under certain conditions, the importance of which is when serum uric acid level elevates in upper two-thirds of normal range [29].Xanthine oxidase, besides its function in purine metabolism, is also involved in superoxide anion generation. Study by [30], demonstrated that superoxide anion can be generated in the kidney by xanthine oxidoreductase and NADPH oxidase.

Treatment of hyperuricemic rat with AP significantly decreased the $\mathrm{XO}$ level $(1.964 \mathrm{ng} / \mathrm{ml})$ and significantly reduced the level of $\operatorname{LPO}(36.15 \mathrm{ng} / \mathrm{ml})$, while significantly increased the SOD1 level (1.673 $\mathrm{ng} / \mathrm{ml}$ ).This result is line with previous study of [22], who showed that oral administration of allopurinol $(5 \mathrm{mg} / \mathrm{kg} / \mathrm{bw})$ daily for 28 days significantly reduced $\mathrm{XO}$ level in the hyperuricemic rats. Moreover, in a study conducted by [31], Patients with newly diagnosed gout were treated with $100-\mathrm{mg}$ allopurinol 8 hour/day for 3 months, Serum uric acid and MDA significantly reduced after one and three months of treatment with allopurinol, while erythrocyte catalase and SOD levels increased significantly after one and three months of treatment with allopurinol. Besides its hypouricemic effect, there is direct and indirect evidence of the antioxidant effect of allopurinol. Allopurinol decreases oxidative stress by decreasing serum uric acid. It also decreases oxidative stress by inhibiting xanthine oxidase and can directly scavenge superoxide anion and hydroxyl radical [31].

Data showed that hyperuricemic rats treated with cherry extract exhibited significantly reduction in serum $\mathrm{XO}$ level (2.202ng/ml). This result is confirmed by [14], in which phenolic compounds reduced XO. Cherry juice inhibited hepatic $\mathrm{XO} / \mathrm{XDH}$ and a significant increase in the serum total antioxidant capacity was observed in cherry juice treated-rats, and oral administration of cherry juice led to a significant reduction $(\mathrm{P} \leq 0.05)$ in MDA concentration in the hyperuricemic rats [7]. Cherry extract treatment also, reduced LPO $(35.20 \mathrm{ng} / \mathrm{ml})$ and increased SOD $(1.770 \mathrm{ng} / \mathrm{ml})$. These results agree with [32] who showed that antioxidant action of cherry juice (mice fed with commercial food pellets with $10 \%$ or $50 \%$ of cherry juice) through increased SOD and Glutathione activity and decreased LPO concentration.

Several studies in animal models and human subjects have demonstrated that phenols are bioavailable and exert a protective role against oxidative stress and free radical damages [33].Cherries have high levels of antioxidants in the form of phenolic compounds and anthocyanins, which improves the capacity to resist oxidative damage during acute oxidative stress [34].

Oral administration of almond oil significantly reduced $\mathrm{XO}(2.763 \mathrm{ng} / \mathrm{ml})$ and LPO $(35.75 \mathrm{ng} / \mathrm{ml})$ levels, and increased SOD1 level $(1.676 \mathrm{ng} / \mathrm{ml})$, indicating the free radical scavenging property of almond oil. These results are confirmed by [35\&36]. The study conducted by [35] revealed the antioxidant and antiradical activities of the almond hull which are higher than those of its shell phenolic extract among different species of almond. As [37] mentioned, almond supplementation can improve antioxidant defenses and reduce biomarkers of oxidative stress in smokers, also reduce serum concentrations of MDA and cholesterol [36].

Almonds are among the richest food sources of vitamin- E, also contains a variety of phenolic compounds [38], the phenolic compounds may inhibit lipid oxidation by scavenging free radicals, chelating metals, activating antioxidant enzymes, reducing tocopherol radicals and inhibiting enzymes that cause oxidation reactions. Moreover, Vitamin-E blocks lipid peroxidation of polyunsaturated fatty acids in membranes, and it protects against lipid peroxidation through its chain-breaking antioxidant activity [39]. Also,[40] reported that vitamin-E improves the activity of SOD.

In the present study, co-treatment of hyperuricemic rats with (cherry extract+ almond oil), showed a highly significant reduction in the levels of XO $(2.096 \mathrm{ng} / \mathrm{ml})$ and LPO $(31.83 \mathrm{ng} / \mathrm{ml})$, but significantly improved SOD1 $(1.848 \mathrm{ng} / \mathrm{ml})$. However, there is no 
study has used these two extracts together, the antioxidant activity of this co-treatment was more than using cherry extract and almond oil individually, this refers to synergetic action of cherry extract +almond oil to reduce oxidative stress.

Table (2)

Effect of cherry extract, almond oil, and their combination on serum XO, LPO, and SODI in hyperuricemic male rats.

\begin{tabular}{||l||c||c|c||}
\hline \hline \multicolumn{1}{|c|}{ Parameters } & \multicolumn{1}{|c|}{$\begin{array}{c}\text { XO } \\
\text { ng/ml }\end{array}$} & $\begin{array}{c}\text { LPO } \\
\text { ng/ml }\end{array}$ & $\begin{array}{c}\text { SOD 1 } \\
\text { ng/ml }\end{array}$ \\
\hline $\begin{array}{l}\text { Normal } \\
\text { (control) rats }\end{array}$ & $2.302 \pm 0.1135^{\mathrm{a}}$ & $30.75 \pm 1.868^{\mathrm{a}}$ & $1.904 \pm 0.2092^{\mathrm{b}}$ \\
\hline $\begin{array}{l}\text { Hyperuricemic } \\
(\text { HU) rats }\end{array}$ & $3.151 \pm 0.1147^{\mathrm{b}}$ & $44.88 \pm 2.346^{\mathrm{b}}$ & $1.025 \pm 0.1344^{\mathrm{a}}$ \\
\hline $\begin{array}{l}\text { HU+ } \\
\text { Allopurinol (AP) }\end{array}$ & $1.864 \pm 0.2333^{\mathrm{a}}$ & $36.15 \pm 0.9430^{\mathrm{a}}$ & $1.673 \pm 0.1040^{\mathrm{b}}$ \\
\hline $\begin{array}{l}\text { HU+ } \\
\text { Cherry extract }\end{array}$ & $2.105 \pm 0.2680^{\mathrm{a}}$ & $35.20 \pm 1.735^{\mathrm{a}}$ & $1.770 \pm 0.1478^{\mathrm{b}}$ \\
\hline $\begin{array}{l}\text { HU+ } \\
\text { Almond oil }\end{array}$ & $2.313 \pm 0.1418^{\mathrm{a}}$ & $35.75 \pm 1.887^{\mathrm{a}}$ & $1.676 \pm 0.1106^{\mathrm{b}}$ \\
\hline $\begin{array}{l}\text { HU+ } \\
\text { (Cherry +Almond oil) }\end{array}$ & $2.096 \pm 0.1176^{\mathrm{a}}$ & $31.83 \pm 2.045^{\mathrm{a}}$ & $1.848 \pm 0.09449^{\mathrm{b}}$ \\
\hline \hline
\end{tabular}

Value expressed as mean \pm S.E. Different letters indicate significant differences between means $*=\mathrm{p}<0.05, * *=\mathrm{p}<0.01, * * *=\mathrm{p}<0.001$

\section{Conclusions}

Oxonic acid injection can cause hyperuricemia, which indicated by anextremely significant increase in the SUA, and hyperuricemia can impair kidney functions and markedly increases oxidative stress. Allopurinol, cherry extract and almond oil, both have hypouricemic action which significantly improves the changes that caused by hyperuricemia. In addition, co-treatments of (cherry extract + almond oil) have more positive effects on hyperuricemia than their treatments alone, and they have effects almost near the actions of allopurinol.

\section{References}

[1] Ottaviani, S., Richette, P., Allard, A., Ora, $\mathrm{J}$. and Bardin, T. Ultrasonography in gout: a case-control study. Clinical and Experimental Rheumatology-Incl Supplements, 30(4), 499, 2012.

[2] Schumacher Jr, H.R. The pathogenesis of gout. Cleveland Clinic Journal of medicine, 75(5), S2, 2008.
[3] Azmi, S.M.N., Jamal, P. and Amid, A. Xanthine oxidase inhibitory activity from potential Malaysian medicinal plant as remedies for gout. International Food Research Journal, 19(1), 159, 2012.

[4] Nuki, G. and Simkin, P.A. A concise history of gout and hyperuricemia and their treatment. Arthritis Research and Therapy, 8(1), 2006.

[5] Chen, I.H., Kuo, M.C., Hwang, S.J., Chang, J.M. and Chen, H.C. Allopurinolinduced severe hypersensitivity with acute renal failure. The Kaohsiung Journal of Medical Sciences, 21(5),228-232, 2005.

[6] Shah, K.H., J.B. Patel, V.J. Shrma, R.M. Shrma, R.P. Patel, and U.M. Chainman. Evaluation of anti diabetic activity of Prunus amygdalus batsch in streptozotocin induced diabetic mice. Research Journal of Pharmaceutical, Biological and Chemical Sciences 2(2): 429-434, 2011.

[7] Haidari, F., Shahi, M.M., Keshavarz, S.A. and Rashidi, M.R. Inhibitory Effects of tart Cherry (Prunus cerasus) Juice on xanthine 
oxidoreductase activity and its hypouricemic and antioxidant effects on rats. Malaysian Journal of Nutrition, 15(1), 2009.

[8] He, Y.H., Zhou, J., Wang, Y.S., Xiao, C., Tong, Y., Tang, J.C.O., Chan, A.S.C. and Lu, A.P. Anti- inflammatory and antioxidative effects of cherries on Freund's adjuvant- induced arthritis in rats. Scandinavian Journal of Rheumatology, 35(5), 356-358, 2006.

[9] Sovilj, M.N. Critical review of supercritical carbon dioxide extraction of selected oil seeds. Acta Per. Technol, 41, 105-120, 2010.

[10] Li, L., Tsao, R., Yang, R., Kramer, J.K. and Hernandez, M. Fatty acid profiles, tocopherol contents, and antioxidant activities of heartnut (Juglans ailanthifolia Var. cordiformis) and Persian walnut (Juglans regia L.). Journal of Agricultural and Food Chemistry, 55(4), 1164-1169, 2007.

[11] Azeez, H.A.; Ibrahim K. M. Hypericum triquetrifolium Callus Cultures a Potential Source of Phenolics and Flavonoids. JZS Part A, Special Issue, Vol. 16, 2014.

[12] Ali, M.A., Al-Hattab, T.A. and AlHydary, I.A. Extraction of date palm seed oil (Phoenix dactylifera) by Soxhlet apparatus. International Journal of Advances in Engineering \& Technology, 8(3), 261, 2015.

[13] Mohamed, D.A. and Al-Okbi, S.Y. Evaluation of anti-gout activity of some plant food extracts. Polish Journal of Food and Nutrition Sciences, 58(3), 2008.

[14] Fei, Y., Ye, D., Fan, X. and Dong, F. Effect of Dioscoreatokoro Makino extract on hyperuricemia in mice. Tropical Journal of Pharmaceutical Research, 15(9), 18831887, 2016.

[15] Alp, H., Aytekin, I., Hatipoglu, N.K., Alp, A. and Ogun, M. Effects of sulforophane and curcumin on oxidative stress created by acute malathion toxicity in rats. Eur Rev Med PharmacolSci, 16(Suppl 3), 144-148, 2012.

[16] Corrado, A., D'Onofrio, F., Santoro, N., Melillo, N. and Cantatore, F.P. Pathogenesis, clinical findings and management of acute and chronic gout.
Minerva Medica, 97(6), 495-509, 2006.

[17] Laksmitawati, D.R., Nurhidayati, L. and Ningsih, N.N. Establishment of Hyperuricemia Mouse Model with Oxonic acid potassium salt and essence of chicken. Research Journal of Pharmaceutical Biological and Chemical Sciences, 8, 6469, 2017.

[18] Hoffmann, D., Fuchs, T.C., Henzler, T., Matheis, K.A., Herget, T., Dekant, W., Hewitt, P. and Mally, A. Evaluation of a urinary kidney biomarker panel in rat models of acute and subchronic nephrotoxicity. Toxicology, 277(1-3), 4958, 2010.

[19] Weiner, D.E., Tighiouart, H., Elsayed, E.F., Griffith, J.L., Salem, D.N. and Levey, A.S. Uric acid and incident kidney disease in the community. Journal of the American Society of Nephrology, 19(6), 1204-1211, 2008.

[20] Kang, D.H., Nakagawa, T., Feng, L., Watanabe, S., Han, L., Mazzali, M., Truong, L., Harris, R. and Johnson, R.J. A role for uric acid in the progression of renal disease. Journal of the American Society of Nephrology, 13(12), 2888-2897, 2002.

[21] Sarvaiya, V.N., Sadariya, K.A., Pancha, P.G., Thaker, A.M., Patel, A.C. and Prajapati, A.S. Evaluation of antigout activity of Phyllanthus emblica fruit extracts on potassium oxonate-induced gout rat model. Veterinary World, 8(10), 1230, 2015.

[22] Goicoechea, M., de Vinuesa, S.G., Verdalles, U., Ruiz-Caro, C., Ampuero, J., Rincón, A., Arroyo, D. and Luño, J. Effect of allopurinol in chronic kidney disease progression and cardiovascular risk. Clinical Journal of the American Society of Nephrology, 5(8), 1388-1393, 2010.

[23] Sanchez-Lozada, L.G., Tapia, E., Santamaria, J., Avila-Casado, C., Soto, V., Nepomuceno, T., Rodriguez-Iturbe, B., Johnson, R.J. and Herrera-Acosta, J. Mild hyperuricemia induces vasoconstriction and maintains glomerular hypertension in normal and remnant kidney rats. Kidney international, 67(1), 237-247, 2005.

[24] Tung, Y.T., Lin, L.C., Liu, Y.L., Ho, S.T., Lin, C.Y., Chuang, H.L., Chiu, C.C., Huang, C.C. and $\mathrm{Wu}$, J.H. Antioxidative 
phytochemicals from Rhododendron oldhamii Maxim. leaf extracts reduce serum uric acid levels in potassium oxonateinduced hyperuricemic mice. BMC Complementary and Alternative Medicine, 15(1), 423, 2015.

[25] Millar, C.L., Duclos, Q. and Blesso, C.N. Effects of dietary flavonoids on reverse cholesterol transport, HDL metabolism, and HDL function. Advances in Nutrition, 8(2), 226-239, 2017.

[26] Zhao, X., Zhu, J.X., Mo, S.F., Pan, Y. and Kong, L.D. Effects of cassia oil on serum and hepatic uric acid levels in oxonateinduced mice and xanthine dehydrogenase and xanthine oxidase activities in mouse liver. Journal of Ethnopharmacology, 103(3), 357-365, 2006.

[27] Sautin, Y.Y. and Johnson, R.J. Uric acid: the oxidant-antioxidant paradox. Nucleosides, Nucleotides, and Nucleic Acids, 27(6-7), 608-619, 2008.

[28] Patterson, R.A., Horsley, E.T. and Leake, D.S. Prooxidant and antioxidant properties of human serum ultrafiltrates toward LDL important role of uric acid. Journal of Lipid Research, 44(3), 512-521, 2003.

[29] Acharya, C., Sharma, A. and Kantharia, N.D. Involvement of oxidative stress in patients of gout and antioxidant effect of allopurinol. Int $\mathrm{J}$ Med Sci Public Health, 4(2), 168-72, 2015.

[30] Wilcox, C.S. Oxidative stress and nitric oxide deficiency in the kidney: a critical link to hypertension?. American Journal of Physiology-Regulatory, Integrative and Comparative Physiology, 289(4), R913R935, 2005.

[31] Pacher, P.A.L., Nivorozhkin, A. and Szabó, C. Therapeutic effects of xanthine oxidase inhibitors: renaissance half a century after the discovery of allopurinol. Pharmacological reviews, 58(1): 87-114, 2006.

[32] Šarić, A., Sobočanec, S., Balog, T., Kušić, B., Šverko, V., Dragović-Uzelac, V., Levaj, B., Čosić, Z., Šafranko, Ž.M. and Marotti, T. Improved antioxidant and antiinflammatory potential in mice consuming sour cherry juice (Prunus cerasus cv. Maraska). Plant Foods for Human Nutrition, 64(4), 231, 2009.
[33] Prior, R.L. Fruits and vegetables in the prevention of cellular oxidative damage. The American Journal of Clinical Nutrition, 78(3), 570S-578S, 2003.

[34] Traustadóttir, T., Davies, S.S., Stock, A.A., Su, Y., Heward, C.B., Roberts, L.J. and Harman, S.M. Tart cherry juice decreases oxidative stress in healthy older men and women. The Journal of nutrition, 139(10), 1896-1900, 2009.

[35] Isfahlan, A.J., Mahmoodzadeh, A., HasAaNnzadeh, A., Heidari, R. and Jamei, R. Antioxidant and antiradical activities of phenolic extracts from Iranian almond (Prunus amygdalus L.) hulls and shells. Turkish Journal of Biology, 34(2), 165-173, 2010.

[36] Jenkins, D.J., Kendall, C.W., Marchie, A., Josse, A.R., Nguyen, T.H., Faulkner, D.A., Lapsley, K.G. and Blumberg, J. Almonds reduce biomarkers of lipid peroxidation in older hyperlipidemic subjects. The Journal of Nutrition, 138(5), 908-913, 2008.

[37] Li, N., Jia, X., Chen, C.Y.O., Blumberg, J.B., Song, Y., Zhang, W., Zhang, X., Ma, G. and Chen, J. Almond consumption reduces oxidative DNA damage and lipid peroxidation in male smokers. The Journal of Nutrition, 137(12), 2717-2722, 2007.

[38] Monaghan, E.K. Chemical composition and protein antigenicity-almond (Prunus dulcis) and macadamia nut (Macadamia integrifolia) seeds. Ph.D. Dissertation, Florida State Univ., United States, 2008.

[39] Serbecic, N. and Beutelspacher, S.C. Anti-oxidative vitamins prevent lipidperoxidation and apoptosis in corneal endothelial cells. Cell and Tissue Research, 320(3), 465-475, 2005.

[40] Shirpoor, A., Salami, S., Khadem-Ansari, M.H., Ilkhanizadeh, B., Pakdel, F.G. and Khademvatani, K. Cardioprotective effect of vitamin E: rescues of diabetes-induced cardiac malfunction, oxidative stress, and apoptosis in rat. Journal of Diabetes and its Complications, 23(5), 310-316, 2009. 